This is an open access article under the CC BY-NC-ND license

Issue IV, November 2021

e-ISSN 2707-9481

Institute of Metallurgy and Ore Beneficiation, Satbayev University, Almaty, Kazakhstan

\author{
Bagdaulet Kenzhaliyev \\ Institute of Metallurgy and Ore \\ Beneficiation, Satbayev University, \\ Republic of Kazakhstan \\ bagdaulet_k@satbayev.university \\ ORCID ID: 0000-0003-1474-8354 \\ Tatiana Surkova \\ Institute of Metallurgy and Ore \\ Beneficiation, Satbayev University, \\ Republic of Kazakhstan \\ E-mail: tu-surkova@mail.ru \\ ORCID ID: 0000-0001-8271-125X
}

\author{
Ainur Berkinbayeva \\ Institute of Metallurgy and Ore \\ Beneficiation, Satbayev University, \\ Republic of Kazakhstan \\ E-mail: ainur_kbk@mail.ru \\ ORCID ID: 0000-0002-2569-9087
}

Zamzagul Dossymbayeva

Institute of Metallurgy and Ore

Beneficiation, Satbayev University,

Republic of Kazakhstan

E-mail: zdos@mail.ru

ORCID ID: 0000-0001-9144-208X

\author{
Dinara Yesimova \\ Institute of Metallurgy and Ore \\ Beneficiation, Satbayev University, \\ Republic of Kazakhstan \\ E-mail: dina-28@inbox.ru \\ ORCID ID: 0000-0002-1582-6732

Bekzat Abdikerim*
Institute of Metallurgy and Ore
Beneficiation, Satbayev University,
Republic of Kazakhstan
E-mail: abdikerim-2030@mail.ru
ORCID ID: 0000-0001-5551-2618

\title{
On methods of modifying natural minerals
}

\begin{abstract}
Recently, more and more attention is paid to the ecological safety of the republic due to the increased threat of environmental pollution by radionuclides, particularly by uranium, while the processing of uranium-containing raw materials generates a significant amount of liquid industrial waste. The main waste disposal method is a sorption, which requires the use of inexpensive sorbents. Such sorbents can be obtained on the basis of domestic natural raw materials. The significant disadvantages of natural sorbents are a low sorption capacity, which can be increased by developing effective and relatively cheap methods for their modification. The absence of the methods of modification is a limiting factor for the widespread using of natural sorbents for environmental purposes. Variants of modification of natural aluminosilicate and coal-mineral raw materials of Kazakhstan by physical and chemical methods are considered. The chemical methods include the modification with a mixture of tributylphostat and di-2ethylhexylphosphoric acid in kerosene to obtain "solid-phase extractants", a mixture of phosphoric acid and polyacrylamide, and the synthesis of organominerals. The possibility of using technogenic raw materials as a modifying reagent has been studied. Zeolite of the previously unexplored Kosmurun deposit and shungite of the Koksu deposit were selected for research, and slags of phosphorus production were selected as a technogenic raw materials. Their physical and chemical properties have been studied.
\end{abstract}

Keywords: natural sorbents, zeolite, shungite, modification, sorption capacity.

Cite this article as: Kenzhaliyev B.; Surkova T.; Berkinbayeva A.; Dossymbayeva Z.; Yesimova D.; Abdikerim B. (2021). On methods of modifying natural minerals. Challenges of Science. Issue IV, pp. 128-133. https://doi.org/10.31643/2021.20

\section{Introduction}

Recently, more and more attention is paid to the ecological safety of the republic, due to the increased threat of environmental pollution by radionuclides, particularly by uranium. While the processing of uranium-containing raw materials, a significant amount of liquid industrial waste is formed, the main method of the processing is sorption, which requires the use of inexpensive sorbents of complex action.

There are in Kazakhstan a significant reserves of mineral raw materials, which are of interest in natural ion-exchange materials. The availability of mineral and coal-mineral raw materials, their low cost, ease of using and existing environmental problems necessitate the production and study of new sorbents with a complex of valuable properties for the extraction of radionuclides. 
Against the background of significant and diverse mineral raw materials with sorption properties, shungites and zeolites occupy a special position as the most studied. The significant disadvantages of natural sorbents include low sorption capacity, which can be increased by developing effective and inexpensive methods for their modification.

The ability of zeolites and zeolite-containing rocks to effectively absorb and retain radionuclides has been shown in many works [1-6].

Various options for obtaining sorbents with improved sorption and kinetic properties are used. For the formation of new adsorption centers, increasing the sorption capacity and selectivity of the sorbent, use inorganic materials modified with amidoxime or iminodiacetate groups, as well as salts of heteropoly acids $[7,8]$. Sorbents with amidoxime groups on various carriers have shown high efficiency in the extraction of radionuclides, as well as good kinetic properties [9-12].

\section{Main Research Part}

To isolate radionuclides from complex technological solutions, sorbents with diphyryl, aminophosphinate, carbamoylmethyl-phosphinate and other phosphorus-containing functional groups have been developed, which are capable of producing stable complexes with radionuclides [13-16].

The synthesis of organopolymers takes a special place in the preparation of modified sorbents. This is how an organozeolite was synthesized based on natural zeolite-containing tuffs and a water-soluble polymer of polyhexamethylguandine, as well as epichlorohydrin as a cross-linking agent, which simultaneously exhibits cation-exchange, anion-exchange and bactericidal properties [17]. The sorbent is highly selective to oxygen-containing anions and uranium carbonate complexes.

All described methods were developed using foreign raw materials. Organopolymers for the sorption of copper (II), lead, and molybdenum ions have been synthesized on the basis of Kazakhstan [18].

At the same time, there are no real methods for obtaining modified sorbents that would have proven themselves well in the processes of uranium sorption. In this regard, the problem of obtaining modified sorbents based on natural raw materials remains relevant for the nuclear industry.

We used a previously unexplored zeolite from the Kosmurun deposit and shungite from the Koksu deposit as an initial raw material.

For research, we used chemical, X-ray phase, thermogravimetric, mineralogical methods of analysis, as well as the method of electron microscopy.

According to physicochemical studies, zeolite has the following elemental and phase composition (Tables 1 and 2).

Table 1 - Elemental composition of the original zeolite

\begin{tabular}{|c|c|c|c|c|c|c|c|c|c|c|c|}
\hline $\mathrm{SiO}_{2}$ & $\mathrm{Al}_{2} \mathrm{O}_{3}$ & $\mathrm{Fe}_{2} \mathrm{O}_{3}$ & $\mathrm{Na}_{2} \mathrm{O}$ & $\mathrm{CaO}$ & $\mathrm{K}_{2} \mathrm{O}$ & $\mathrm{MgO}$ & $\mathrm{P}_{2} \mathrm{O}_{5}$ & $\mathrm{MnO}$ & $\mathrm{TiO}_{2}$ & $\begin{array}{l}\text { Other } \\
\text { impurities }\end{array}$ & $\mathrm{SiO}_{2} / \mathrm{Al}_{2} \mathrm{O}_{3}$ \\
\hline 62,2 & 13,4 & 5,9 & 1,6 & 5,3 & 6,5 & 2,2 & 0,4 & 0,2 & 0,5 & 1,8 & 4,6 \\
\hline
\end{tabular}

Table 2 - Phase composition of the original zeolite

\begin{tabular}{|l|l|c|}
\hline \multicolumn{1}{|c|}{ Name } & \multicolumn{1}{|c|}{ Formula } & Zeolite \\
\hline Clinoptilolite & $(\mathrm{Na}, \mathrm{K}, \mathrm{Ca})_{6}(\mathrm{Si}, \mathrm{Al})_{36} \mathrm{O}_{72} \cdot 2 \mathrm{H}_{2} \mathrm{O}$ & 21.5 \\
\hline Quartz & $\mathrm{SiO}_{2}$ & 21.3 \\
\hline \multicolumn{1}{|c|}{ Albite } & $\mathrm{Na}\left(\mathrm{AlSi} \mathrm{O}_{8}\right)$ & 19.4 \\
\hline Diopside & $\mathrm{Ca}(\mathrm{Mg}, \mathrm{Al})(\mathrm{Si}, \mathrm{Al})_{2} \mathrm{O}_{6}$ & 13.9 \\
\hline Hematite & $\mathrm{Fe}_{2} \mathrm{O}_{3}$ & 9.3 \\
\hline Lomontitis & $\mathrm{Ca}\left(\mathrm{H}_{2} \mathrm{O}\right) 2.8\left(\mathrm{Al}{ }_{2} \mathrm{Si}_{4} \mathrm{O}_{12}\right)\left(\mathrm{H}_{2} \mathrm{O}\right) \cdot 5$ & 7.8 \\
\hline Erinith & $\left(\left(\mathrm{Fe}^{+2}, \mathrm{Fe}^{+3}, \mathrm{Al}\right) 3 \mathrm{Mg} 3(\mathrm{Ca}, \mathrm{Na}) 4(\mathrm{Si13} .5 \mathrm{Al} 4.5 \mathrm{O} 42)(\mathrm{OH})_{6}\right) \cdot 11.3 \mathrm{H}_{2} \mathrm{O}$ & 6.8 \\
\hline
\end{tabular}

Figure 1 shows the results of a thermogravimetric study of a sample of the original zeolite.

DTA analysis shows that an endothermic effect with extrema at $236^{\circ} \mathrm{C}, 364^{\circ} \mathrm{C}$ and an exothermic effect with a peak at $749.5^{\circ} \mathrm{C}$ were recorded, which can be interpreted as a manifestation of harmotom 
zeolite - $\mathrm{Ba}\left[\mathrm{Al}_{2} \mathrm{Si}_{6} \mathrm{O}_{16}\right]$. The first two effects reflect the stepwise dehydration, the exothermic effect - the destruction of the lattice, amorphization of the decay products. The combination of the endothermic effect with maximum development at $236^{\circ} \mathrm{C}$ (dDTA curve) and the exothermic effect with a peak at $822.8^{\circ} \mathrm{C}$ (dDTA curve) may reflect the presence of chabazite zeolite - $\left(\mathrm{Ca}, \mathrm{Na}_{2}\right)\left(\mathrm{Al}_{2} \mathrm{Si}_{4} \mathrm{O}_{12}\right) 6 \mathrm{H}_{2} \mathrm{O}$.. In the area of the development of the endothermic effect, the process of dehydration takes place, and in the area of the exothermic effect, the process of destruction of the crystal structure with the formation of an X-ray amorphous phase. The combination of an exothermic effect with a peak at $464.6^{\circ} \mathrm{C}$ (DTA curve) and an endothermic effect with a maximum development at $236^{\circ} \mathrm{C}$ (dDTA curve) may be a manifestation of calcium-type clinoptilolite $\mathrm{Ca}\left[\mathrm{Al}_{2} \mathrm{Si}_{7} \mathrm{O}_{18}\right] 6 \mathrm{H}_{2} \mathrm{O}$.

The endothermic effect with a maximum development at $582.8^{\circ} \mathrm{C}$ (DTA curve) could manifest itself as a result of the implementation of various processes in various phases. The dDTA curve shows that this effect breaks down into two effects - with extremes at $553.5^{\circ} \mathrm{C}$ and $573.4^{\circ} \mathrm{C}$. There are also two minima on the DTG curve - at $555.9^{\circ} \mathrm{C}, 571.7^{\circ} \mathrm{C}$. Therefore, in the area of its development, dehydration of the analcime zeolite $-\mathrm{Na}_{2}\left[\mathrm{AlSi}_{2} \mathrm{O}_{6}\right] \cdot 2 \mathrm{H}_{2} \mathrm{O}$ is possible. Also, dehydration of impurities of some clay minerals is likely here illite (hydromica) $(\mathrm{Ca}, \mathrm{Na}) \mathrm{Al}_{2}\left[(\mathrm{OH})_{2} \mathrm{AlSi}_{3} \mathrm{O}_{10}\right]\left(\mathrm{H}_{2} \mathrm{O}\right)_{2}$, afrosiderite (ferrous chlorite) - $2 \mathrm{SiO}_{2} \mathrm{Al}_{2} \mathrm{O}_{3}(\mathrm{FeO}) \cdot \mathrm{H}_{2} \mathrm{O}$. In superimposition, the endothermic effect with a maximum development at $573.4^{\circ} \mathrm{C}$ may be a manifestation of the polymorphic transformation of quartz $\left(\mathrm{SiO}_{2}\right)$. The endothermic effect with the maximum development at $721.7^{\circ} \mathrm{C}$ can be a reflection of the dissociation of calcite, and the endothermic effect with the maximum development at $853.3^{\circ} \mathrm{C}$ (dDTA curve) is a reflection of the transition of the calisilite impurity $\left(\mathrm{K}_{2} \mathrm{OAl}_{2} \mathrm{O}_{3} \cdot \mathrm{nSiO}_{2}\right)$ from the hexagonal to the rhombic modification. This same effect, in overlay, can reflect the decay of the illite lattice. The endothermic effect with an extremum at $788.1^{\circ} \mathrm{C}$ can be a manifestation of dehydration of an admixture of finely dispersed muscovite $-\mathrm{K}_{2} \mathrm{O}_{3} \mathrm{Al}_{2} \mathrm{O}_{3} 6 \mathrm{SiO}_{2} \cdot 2 \mathrm{H}_{2} \mathrm{O}$. A weak exothermic effect with a peak at $995.6^{\circ} \mathrm{C}$ may reflect the crystallization of illite lattice decomposition products.

In superimposition, a combination of endothermic and exothermic effects in the temperature range of $100-600^{\circ} \mathrm{C}$ can be a manifestation of iron hydroxides - goethite, lepidocrocite, amorphous hydroxide.

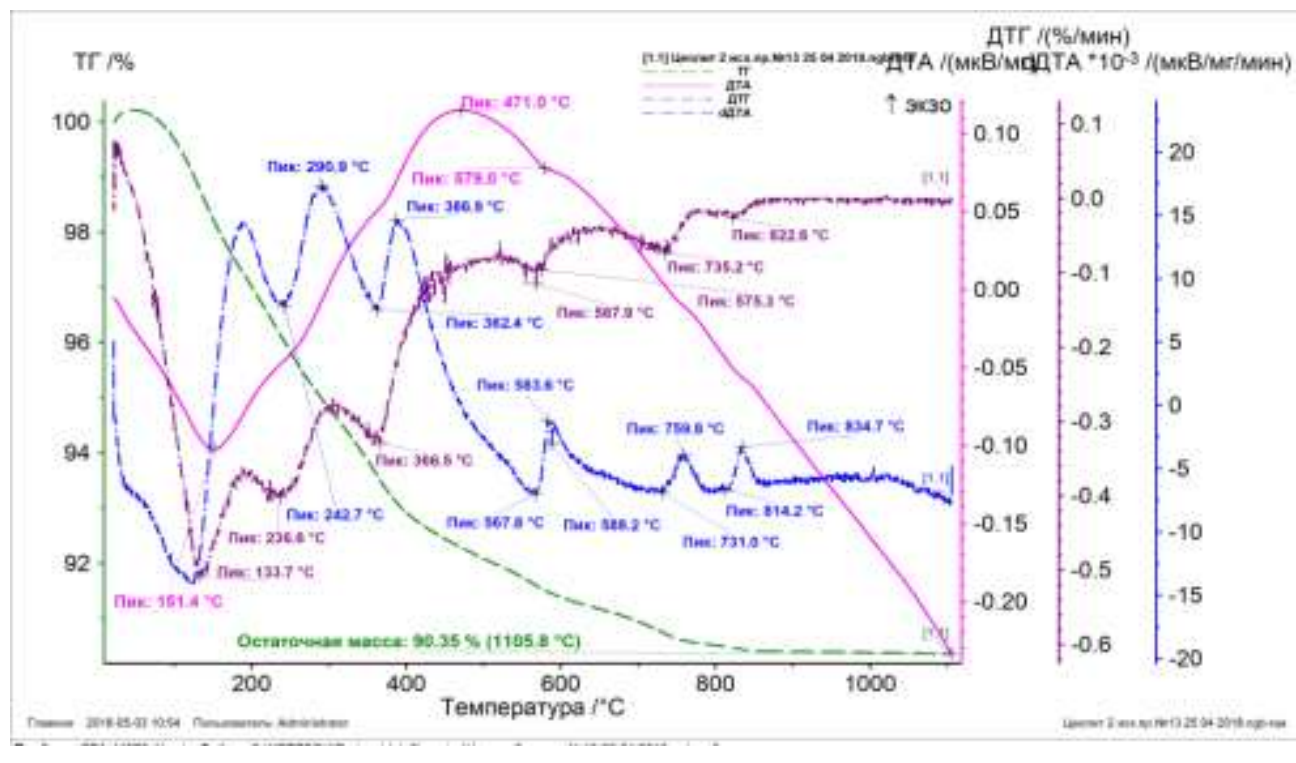

Figure 1 - Zeolite thermogram

Deep mineralogical studies, as well as data obtained with the JXA-8230 electron probe microanalyzer from JEOL, also showed a complex composition and noted the structural features of the initial raw materials. In particular, comprehensive physicochemical studies have confirmed that the mineral belongs to the calcium-type zeolite, which is not typical for the studied zeolite raw materials of Kazakhstan; it is distinguished by structural features inherent in calcium-type clinoptilolite.

Shungite is a unique natural formation, lying in the form of shungite rocks and representing a compacted mechanical mixture, the main components of which are finely dispersed phases of noncrystalline carbon and silicon dioxide, which form a single composite system. The elemental composition of shungite is 
presented in Table 3. According to X-ray phase analysis, the shungite of the Koksu deposit consists of quartz, siderite, muscovite, albite and clinochlore.

Table 3 - Shungite composition

\begin{tabular}{|c|c|c|c|c|c|c|c|c|c|c|c|c|c|}
\hline $\mathrm{C}$ & $\mathrm{K}$ & $\mathrm{Al}$ & $\mathrm{Si}$ & $\mathrm{Fe}$ & $\mathrm{S}$ & $\mathrm{Na}$ & $\mathrm{Mg}$ & $\mathrm{P}$ & $\mathrm{Ca}$ & $\mathrm{Ti}$ & $\mathrm{V}$ & $\mathrm{O}$ & $\mathrm{Mn}$ \\
\hline 15,0 & 0,83 & 3,52 & 14,9 & 2,9 & 0,05 & 0,12 & 0,90 & 0,26 & 16,43 & 0,26 & 0,16 & 43,2 & 0,12 \\
\hline
\end{tabular}

Natural shungite, like zeolite, has a low sorption capacity for uranium.

In the process of research, three options for the technology of shungite beneficiation by flotation were proposed and tested. The optimal variant was turned out to provide for froth flotation of shungite rock, preliminarily crushed to a fraction of 71 microns, with the addition of lime to create a pH of the medium equal to 8.0-9.0 and water glass for depression of gangue minerals. Kerosene was used as a collector, and T80 was used as a blowing agent. The composition of shungite concentrate is shown in Table 4. The flotation scheme is shown in Figure 2.

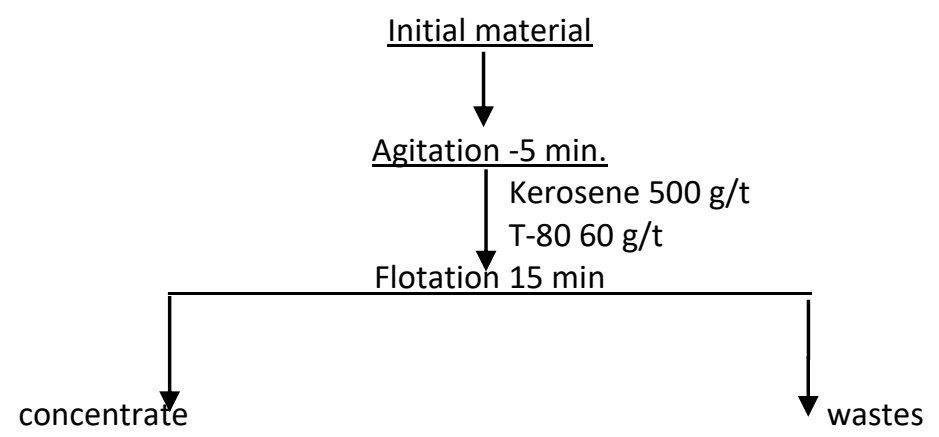

Figure 2 - Shungite flotation scheme

Table 4 - Shungite composition of the Koksu deposit after flotation

\begin{tabular}{|c|c|c|c|c|c|c|c|c|c|c|c|c|c|c|c|}
\hline \multirow[t]{2}{*}{ Product name } & \multirow{2}{*}{$\begin{array}{l}\text { Out } \\
\text { put, } \\
\%\end{array}$} & \multicolumn{7}{|c|}{ Content, \% } & \multicolumn{7}{|c|}{ recovery, $\%$} \\
\hline & & C & $\mathrm{O}$ & $\mathrm{Al}$ & $\mathrm{Si}$ & $S$ & K & $\mathrm{Fe}$ & C & 0 & $\mathrm{Al}$ & $\mathrm{Si}$ & $S$ & K & $\mathrm{Fe}$ \\
\hline \multicolumn{16}{|c|}{ Test №3 } \\
\hline Concentrate & 43,2 & 21,0 & 40,9 & 3,29 & 14,8 & 0,05 & 0,77 & 3,1 & 60,5 & 40,8 & 40,3 & 42,9 & 47,9 & 39,9 & 46,1 \\
\hline Wastes & 56,8 & 10,4 & 45,0 & 3,7 & 14,9 & 0,04 & 0,88 & 2,8 & 39,5 & 59,2 & 59,7 & 57,1 & 52,1 & 60,0 & 53,9 \\
\hline Ore & 100 & 15,0 & 43,2 & 3,52 & 14,9 & 0,05 & 0,83 & 2,9 & 100 & 100 & 100 & 100 & 100 & 100 & 100 \\
\hline
\end{tabular}

It follows from the table that in the process of flotation shungite enrichment in carbon is observed, in the resulting concentrate the carbon content increased to $21 \%$. X-ray phase studies have shown that with the enrichment of shungite, the content of quartz decreases, dolomite is almost completely transformed, the content of siderite, microcline, albite and muscovite increases, and new phases appear, such as clinochlore and epidote.

As mentioned above, natural minerals have a low sorption capacity $[19,20,21]$, which can be increased by modification.

In the course of our research, we have developed and tested physical and chemical methods for modifying natural minerals.

Ultrasonic activation is one of the modern ways to accelerate the course of various chemical processes. Analysis of literature data shows that ultrasonic treatment of sorbents in a liquid medium contributes to the emergence of cavitation, which is one of the main reasons for the acceleration of physicochemical processes, which leads to the intensification of the sorption extraction of components from a liquid medium. However, in some cases, the effect of ultrasound on the sorbent can be one of the reasons for reducing its mechanical strength, especially of natural sorbents. In this regard, it was proposed to act not on sorbents, but on a liquid medium (chemical reagents) with their subsequent activation of natural materials $[22,23]$. 
Chemical methods of modification included the treatment of natural minerals with organic extractants, phosphoric acid in combination with polyacrylamide by the method of obtaining "solid-phase extractants", as well as the synthesis of organominerals based on natural sorbents and organic compositions. Organic compositions were formed on the basis of dimethylformamide (DMF), glycidyl methaacrylate (GMA), and a solution of oxyethylene diphosphonic (OEDP) acid in the presence of a catalyst of $0.02 \%$ benzoyl peroxide (PB). All three options have proved to be good in uranium sorption tests.

The uranium content in waste solutions, as a rule, is $5-15 \mathrm{mg} / \mathrm{dm}^{3}$. In this regard, we have adjusted the productive solution in accordance with the given uranium concentration and studied the sorption process by modified zeolite and shungite. The kinetic dependences of the sorption of uranium in a static mode from the imitate showed that it is possible to extract uranium by more than $90 \%$ with modified sorbents already in the first 45 - 50 minutes.

These modified sorbents can be used for analytical purposes, as well as in low-tonnage production conditions. Their widespread use for the disposal of large volumes of liquid uranium-containing waste is unprofitable. Currently, work in this direction continues. In order to reduce the cost of modified sorbents, studies are being conducted on the possibility of using technogenic raw materials as modifiers, in particular, phosphorus slag, which is a waste of the phosphorus industry and is formed during the electrothermal production of yellow phosphorus. According to the conducted physicochemical studies, the main phase of the phosphorus slag - calcium silicate - is represented by the amorphous phase of volostanite. The slag also contains small amounts of calcite and ankerite, phosphorus is present in the form of lazulite.

Studies in the field of calcium silicate synthesis have shown that rational and environmentally friendly options include methods based on the interaction of initial components in an aqueous medium at elevated temperatures and, in some cases, pressure, i.e. hydrothermal method. The hydrothermal method allows not only the synthesis of hydrosilicates, but also affects their structure and particle morphology. Hydrothermal conditions simulate the formation of minerals in the earth's interior. As the aqueous phase, calcium salts and sodium chloride are usually used.

\section{Conclusion}

To sum up, it was found that during the hydrothermal treatment of slag in a carbonate medium, with an increase in temperature, the amorphous phase is transformed into a crystalline phase, and the morphology of particles also changes: the conglomerates existing in the initial sample gradually change their shape and turn into particles of an acicular structure. During the hydrothermal treatment of phosphorus slag with sodium chloride, its amorphous structure is retained.

Several options for modifying natural minerals have been developed. An indicator of one or another modification method is the sorption process.

Studies have shown that the sorption capacity of modified sorbents increases when natural minerals are dressed with phosphoric slag, activated in a chloride medium, and iron in a carbonate medium. This technique can be used to separate them.

Conflicts of interest. On behalf of all authors, the corresponding author states that there is no conflict of interest.

Acknowledgements. This work was supported by Committee of Science of the Ministry of Education and Science of Republic of Kazakhstan with the grant No. AR 05131104.

Cite this article as: Kenzhaliyev B.; Surkova T.; Berkinbayeva A.; Dossymbayeva Z.; Yesimova D.; Abdikerim B. (2021). On methods of modifying natural minerals. Challenges of Science. Issue IV, pp. 128-133. ～https://doi.org/10.31643/2021.20

\section{References}

1. Dell'Aglia, G., Feronea C., Mascolob M.C. Thermal transformation of Ba-exchanged A and X zeolites into monoclinic celsian. Solid State lonics. - 2000. - V. 127, № 3-4. - P. 309-317.

2. Myasoedova V.G., Nikashina V.A. Sorption materials for the extraction of radionuclides from aqueous media. Ros. chem. $j$. - 2006. - T.L, №5. pp. 55-61. 
3. Kardashev, G.A. Physical methods of intensification of chemical technology processes. - M.: Chemistry, 1990. -208 p.

4. Promtov M.A. Prospects for the use of cavitation technologies for the intensification of chemical-technological processes. Bulletin of the Tambov State Technical University. - 2008. - T. 14, № 4. - C. 861-869.

5. Khmelev V.N., Slivin A.N., Barsukov R.V. and et al. Application of high-intensity ultrasound in industry. - Biysk: Altai Technical University, 2010. - 203 p.

6. Srivastava P., Goyal S., Tayade R. Ultrasound-assisted adsorption of reactive blue 21 dye onTiO2 in the presence of some rare earths (La, Ce, $\operatorname{Pr} \&$ Gd). The Canadian Journal of Chemical Engineering. - 2014. - V. 92. - P. 41-51.

7. Milyutin V.V. Gelis V.M., Penzin P.A. Sorption-selective characteristics of inorganic sorbents and ion-exchange resins in relation to cesium and strontium. Radiochemistry. 1993. T.35. №3. C.76-82.

8. Dunaeva A.N., Mironenko M.V. Sorption of cesium by some clay minerals. Geochemistry. 2000. №2. Pp. 213-221.

9. Myasoedova G.V., Nikashina V.A., Molochnikova N.P., Lileeva L.V. Properties of new types of fibrous sorbents with amidoxime and hydrazine groups. Journal of Analytical Chemistry. 2000, Vol.55, №6, pp.611-615

10. Donald, I. W. The immobilization of high level radioactive waste using ceramics and glasses (Review) / I. W.Donald, R. N. Metcalfe, R. N. J. Taylor. J. Mater. Sci. - 1997. - V. 32. - P. 5851-5887.

11. Druzhinina T.V., Smolenskaya L.M., Struganova M.A. Sorption of heavy metals from model solutions by amine-containing chemisorption polyamide fiber. Journal of Applied Chemistry. 2003. T. 76, №12. pp. 1976-1980

12. Ma W. P., Brown P. W., Komarneni S. Characterization and cation exchange properties of zeolite synthesized from fly ashes. J. Mater. Res. - 1998. - V. 13. - P. 3-7.

13. Kosanovic, C., Subotic C., Ristic B. A., [et al.] Kinetic analysis of non-isothermal transformation of zeolite 4A into lowcarnegieite. Croat. Chem. Acta. - 2004. - V. 77, № 4. - P. 553-560.

14. Subramanian, M. A. Zeolites as precursors to aluminosilicate-based ceramics for microelectronic packaging / M. A. Subramanian, D. R. Corbin, U. Chowdhry. Adv. Ceram. Key Eng. Mat. - 1989. - V. 26. - P. 239-247.

15. Cruciani, G. Zeolites upon heating: Factors governing their thermal stability and structural changes / G. Cruciani. J. Phys. Chem. Solids. - 2006. - V. 67, № 9-10. - P. 1973-1994.

16. Dell'Aglia, G. Thermal transformation of Ba-exchanged A and X zeolites into monoclinic celsian / G. Dell'Aglia, C. Feronea, M.C. Mascolob et al. Solid State lonics. - 2000. - V. 127, № 3-4. - P. 309-317.

17. Panasyugin A.S., Troftmenko N.E., Masherova N.P., Ratko A.I., Golikova N.I. Sorption of radionuclides Radiochemistry, 1993. T. 66. №9, стр. 2119-2122.

18. Ergozhin E.E., Akimbaeva A.M. Organomineral sorbents and polyfunctional systems based on natural and coal-mineral raw materials. - Almaty, 2007, $307 \mathrm{p}$.

19. Kenzhaliyev B.K., Imangalieva L.M., Manapova A.I., Azlan M.N. (2021). Kaolinite clays as a source of raw materials for the aluminum industry of the Republic of Kazakhstan. Kompleksnoe Ispol'zovanie Mineral'nogo Syr'a = Complex Use of Mineral Resources. Volume 4, Issue 319, pp. 5-12. https://doi.org/10.31643/2021/6445.34

20. Kenzhaliev B. K., Surkova T. Yu., Berkinbayeva A. N., Dosymbayeva Z. D., Chukmanova M. T. To the question of recovery of uranium from raw materials. News of National Academy of Sciences of the Republic of Kazakhstan, 2019, 1 (433), P. 112-120. DOI: $10.32014 / 2019.2518-170 X .14$

21. Kenzhaliev B.K., Kvyatkovsky S. A., Kozhakhmetov S. M., Sokolovskaya L. V., Semenova A. S. (2018). Depletion of waste slag of balkhash copper smelter. Kompleksnoe Ispol'zovanie Mineral'nogo syr'â = Complex Use of Mineral Resources. 306 (3), 45-53 (In Rus.). https://doi.org/10.31643/2018/6445.16

22. Kenzhaliev B.K., Kvyatkovskii S.A., Kozhakhmetov S.M., Sokolovskaya L.V., Kenzhaliev É.B., Semenova A.S. Determination of optimum production parameters for depletion of balkhash copper-smelting plant dump slags. Metallurgist, 63 (7), $759-765$

23. Method for extracting uranium by sorption / Invention patent № 2019/0116.1 № 34401 B. K. Kenzhaliyev, T.Yu. Surkova, A. N. Berkinbayeva, Z.D. Dosymbayeva, Chukmanova M.T., B.E. Abdikerim. 